Nova Southeastern University

Florida

NOVA SOUTHEASTERN

UNIVERSITY

NSUWorks

Marine \& Environmental Sciences Faculty Articles Department of Marine and Environmental Sciences

$10-1-2012$

\title{
Development and Characterization of 11 Novel Microsatellite Loci for the Roundscale Spearfish Tetrapturus georgii and Their Cross-Species Amplification Among Other Istiophorid Species
}

Andrea M. Bernard

Nova Southeastern University, andrbern@nova.edu

Kevin A. Feldheim

Pritzker Laboratory for Molecular Systematics and Evolution

Mahmood S. Shivji

Nova Southeastern University, mahmood@nova.edu

Find out more information about Nova Southeastern University and the Halmos College of Natural Sciences and Oceanography.

Follow this and additional works at: https://nsuworks.nova.edu/occ_facarticles

Part of the Genetics and Genomics Commons, Marine Biology Commons, and the Oceanography and Atmospheric Sciences and Meteorology Commons

\section{NSUWorks Citation}

Andrea M. Bernard, Kevin A. Feldheim, and Mahmood S. Shivji. 2012. Development and Characterization of 11 Novel Microsatellite Loci for the Roundscale Spearfish Tetrapturus georgii and Their Cross-Species Amplification Among Other Istiophorid Species .Journal of Fish Biology, (5) : 1781 -1786. https://nsuworks.nova.edu/occ_facarticles/359.

This Article is brought to you for free and open access by the Department of Marine and Environmental Sciences at NSUWorks. It has been accepted for inclusion in Marine \& Environmental Sciences Faculty Articles by an authorized administrator of NSUWorks. For more information, please contact nsuworks@nova.edu. 


\title{
Development and characterization of 11 novel microsatellite loci for the roundscale spearfish Tetrapturus georgii and their cross-species amplification among other istiophorid species
}

\author{
A. M. Bernard*, K. A. Feldheim† And M. S. Shivji* ${ }^{*}$ \\ *Guy Harvey Research Institute, Oceanographic Center, Nova Southeastern University, 8000 \\ North Ocean Drive, Dania Beach, FL 33004, U.S.A. and †The Field Museum of Natural \\ History, Pritzker Laboratory for Molecular Systematics and Evolution, 1400 South Lake \\ Shore Drive, Chicago, IL 60605, U.S.A.
}

(Received 19 March 2012, Accepted 18 July 2012)

\begin{abstract}
Eleven novel polymorphic microsatellite loci were developed and characterized for the recently validated roundscale spearfish Tetrapturus georgii. Characterization of these markers, based on 35 roundscale spearfish from the western North Atlantic, revealed two to 21 alleles per locus with an average expected heterozygosity $\left(H_{\mathrm{E}}\right)$ of $0 \cdot 09-0.94$, and all loci conformed to HardyWeinberg expectations. Cross-amplification of these 11 loci against all other eight known istiophorid species indicates promising prospects for the utility of these markers for istiophorids in general.

(C) 2012 The Authors

Journal of Fish Biology (C) 2012 The Fisheries Society of the British Isles
\end{abstract}

Key words: Atlantic; billfish; Istiophoridae; population genetics; primer sequence.

There is increasing concern about the population status of many billfish (Istiophoridae) species as they are heavily fished in pelagic fisheries either as targets or by-catch, and their management is made complex due to the international nature of their fisheries (Collette et al., 2011a). Adding to this management complexity is that one billfish, the roundscale spearfish Tetrapturus georgii Lowe 1841, was only recently validated as a legitimate species (Shivji et al., 2006). The lack of historical recognition of $T$. georgii is due to its strong morphological similarity to the sympatric white marlin Kajikia albida (Poey 1860), itself a severely overfished and IUCN Red List vulnerable species (Collette et al., 2011a,b). To make matters worse, it is now clear that $T$. georgii has also frequently been misidentified as the longbill spearfish Tetrapturus pfluegeri Robins \& de Sylva 1963, another very similar looking billfish species (unpubl. data).

Given its recent validation, almost nothing is known about the biology and population structure of $T$. georgii. The species is currently listed as data deficient on the IUCN Red List (Collette et al., 2011b). It is suspected to be a solitary species capable 


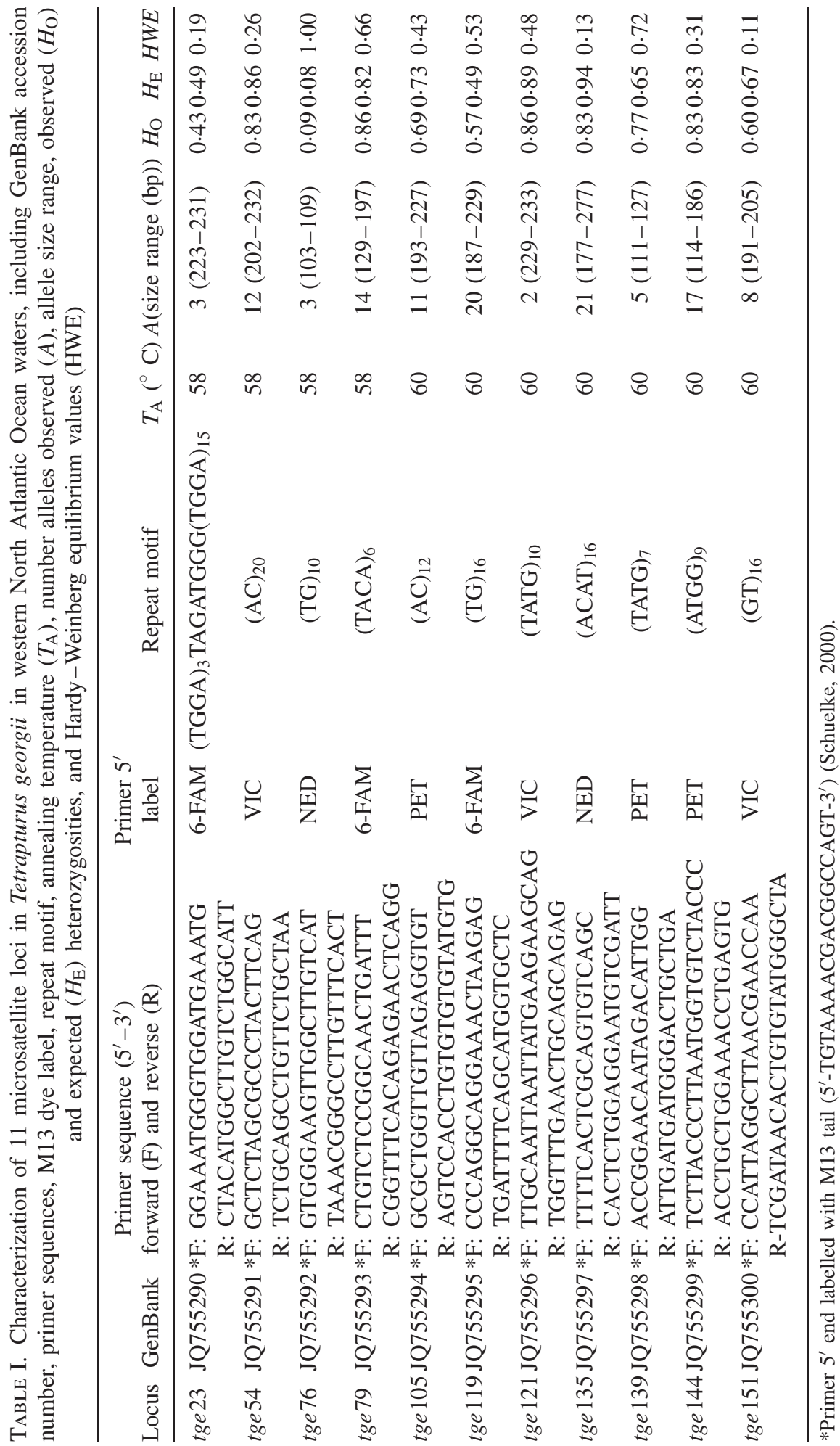




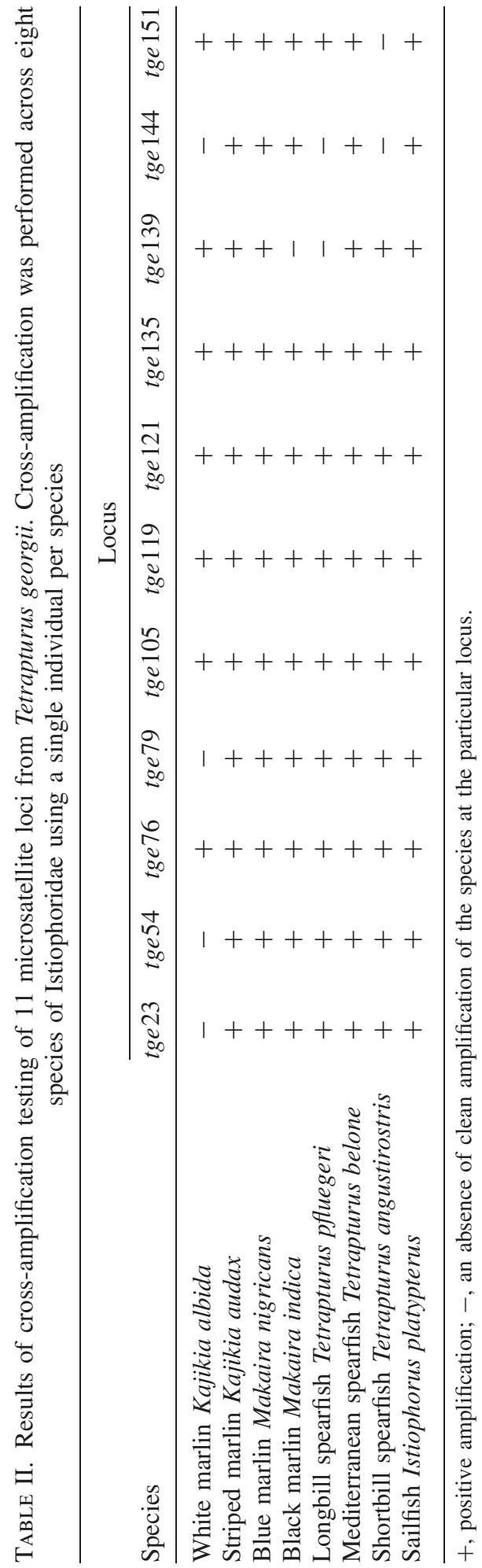


of extensive migrations (Arocha \& Ortiz, 2006), and probably plays an ecosystem role as an apex predator like other istiophorid species. Of concern from a conservation and management perspective is that $T$. georgii may have been subject to similar levels of overexploitation as K. albida (Beerkircher et al., 2009). Understanding the life history, population structure, evolutionary history and fishery dynamics of $T$. georgii is therefore of great importance for conservation and management purposes.

The development and characterization of 11 microsatellite loci markers for assisting with these efforts is reported here. The cross-species amplification performance of these markers on eight other istiophorid species of conservation and management interest is also presented. Tissue samples (fin clips) were collected from 35 T. georgii individuals captured in western North Atlantic Ocean pelagic fisheries. The samples were stored in $95 \%$ ethanol until DNA extraction. Genomic DNA (gDNA) was extracted from $25 \mathrm{mg}$ of tissue using the DNeasy Kit (QIAGEN; www.qiagen.com) following the manufacturer's protocol.

Microsatellite marker development was performed utilizing Glenn \& Schable's (2005) enrichment protocol. gDNA from a single $T$. georgii was digested using BstUI and XmnI, followed by ligation of SuperSNX24 linkers to the ends of the digested gDNA fragments to act as priming sites for subsequent polymerase chain reactions $(\mathrm{PCR})$. Biotinylated tetranucleotide probes $\left[(\mathrm{AAAT})_{8},(\mathrm{AACT})_{8},(\mathrm{AAGT})_{8}\right.$, $(\mathrm{ACAT})_{8}$ and $\left.(\mathrm{AGAT})_{8}\right]_{\text {were }}$ wybridized to the gDNA fragments. The biotinylated probe-gDNA complex was then added to magnetic beads coated with streptavidin (Dynabeads M-280: Invitrogen; www.invitrogen.com) and washed twice with $\times 2$ sodium chloride, sodium citrate (SSC), 0.1\% sodium dodecyl sulphate (SDS) and four times with $1 \times \mathrm{SSC}, 0.1 \% \mathrm{SDS}$ at $52^{\circ} \mathrm{C}$. For the final two washes, the solution was incubated at $52^{\circ} \mathrm{C}$ for $1 \mathrm{~min}$. Enriched fragments were removed from the biotinylated probes by denaturation at $95^{\circ} \mathrm{C}$ and subsequently precipitated using $95 \%$ ethanol and $3 \mathrm{M}$ sodium acetate. To increase the amount of enriched fragments, a recovery PCR was performed in a $25 \mu \mathrm{l}$ reaction containing $1 \times$ PCR buffer $(10 \mathrm{mM}$ Tris- $\mathrm{HCl}, 50 \mathrm{mM} \mathrm{KCl}, \mathrm{pH} 8 \cdot 3), 1.5 \mathrm{mM} \mathrm{MgCl}_{2}, 0.16 \mathrm{mM}$ of each deoxynucleotide triphosphate (dNTP), $10 \times$ bovine serum albumin (BSA), $0.52 \mu \mathrm{M}$ of the SuperSNX24 forward primer, 1U Taq DNA polymerase (QIAGEN), and c. $25 \mathrm{ng}$ enriched gDNA fragments. Thermal cycling was performed in a Bio-Rad DYAD (Bio-Rad; www.bio-rad.com) as follows: $95^{\circ} \mathrm{C}$ for $2 \mathrm{~min}$, followed by 25 cycles of $95^{\circ} \mathrm{C}$ for $20 \mathrm{~s}, 60^{\circ} \mathrm{C}$ for $20 \mathrm{~s}$ and $72^{\circ} \mathrm{C}$ for $90 \mathrm{~s}$ and a final elongation step of $72^{\circ} \mathrm{C}$ for 30 min. The resulting PCR fragments were cloned using the TOPO-TA Cloning kit following the manufacturer's protocol (Invitrogen). Bacterial colonies containing a vector with gDNA were used as a template for subsequent PCR in a $25 \mu 1$ reaction containing $1 \times$ PCR buffer $(10 \mathrm{mM}$ Tris $-\mathrm{HCl}, 50 \mathrm{mM} \mathrm{KCl}, \mathrm{pH} 8.3), 1.5 \mathrm{mM}$ $\mathrm{MgCl}_{2}, 0.12 \mathrm{mM}$ of each dNTP, $10 \times \mathrm{BSA}, 0.25 \mu \mathrm{M}$ of the M13 primers and $1 \mathrm{U}$ Taq DNA polymerase. Thermal cycling was as follows: an initial denaturing step of $95^{\circ} \mathrm{C}$ for $7 \mathrm{~min}$, followed by 35 cycles of $95^{\circ} \mathrm{C}$ for $20 \mathrm{~s}, 50^{\circ} \mathrm{C}$ for $20 \mathrm{~s}$ and $72^{\circ} \mathrm{C}$ for $90 \mathrm{~s}$. PCR products were subsequently cleaned using MultiScreen-PCR Filter plates following the manufacturer's protocol (Millipore; www.millipore.com), and sequenced using the BigDye Terminator v3.1 Cycle Sequencing Kit (Applied Biosystems; www.appliedbiosystems.com). Sequencing reactions were precipitated with ethanol and $125 \mathrm{mM}$ EDTA and run on a 3730 DNA Analyzer (Applied Biosystems). Primers flanking core microsatellite repeats were developed using Primer3 
(Rozen \& Skaletsky, 2000). A total of 74 primer pairs were tested to determine amplification success and relative levels of polymorphism. Of these primer pairs, 11 amplified $T$. georgii consistently and showed evidence of polymorphism. Characterization of these loci was subsequently performed on 35 individuals.

All microsatellite PCRs were conducted in a total reaction volume of $25 \mu \mathrm{l}$ and contained $1 \mu \mathrm{l}$ of unquantified genomic DNA, $1 \times$ PCR buffer, $0.2 \mathrm{mM}$ of each dNTP, $0.33 \mathrm{mM} \mathrm{MgCl}_{2}, 0.4 \mu \mathrm{M}$ of the fluorescently labelled universal M13 primer $\left(5^{\prime}\right.$-TGTAAAACGACGGCCAGT-3') and the species-specific reverse primer, $0 \cdot 16 \mu \mathrm{M}$ of the species-specific forward primer with a $5^{\prime}-\mathrm{M} 13$ tail (Schuelke, 2000) and $0 \cdot 5 \mathrm{U}$ of HotStar Taq DNA Polymerase (QIAGEN). PCR was performed in a Mastercycler Gradient (Eppendorf; www.eppendorf.com) thermal cycler as follows: an initial denaturing step of $95^{\circ} \mathrm{C}$ for $15 \mathrm{~min}$, followed by 35 cycles of $94^{\circ} \mathrm{C}$ for $1 \mathrm{~min}, 1 \mathrm{~min}$ at the primer annealing temperature (Table I), $72^{\circ} \mathrm{C}$ for $1 \mathrm{~min}$, followed by a final extension of $20 \mathrm{~min}$ at $72^{\circ} \mathrm{C}$. Amplification products were resolved on an AB3130 genetic analyser (Applied Biosystems) and scored using LIZ 600 as the internal allele size standard and the software GeneMapper 3.7 (Applied Biosystems).

Expected and observed heterozygosities and departures from Hardy-Weinberg (HWE) and linkage equilibrium (LE) were assessed using the software Genepop v4.0 on the web (Raymond \& Rousset, 1995; Rousset, 2008). Significance was estimated using Fisher's exact test (1000 dememorizations, 100 batches and 1000 iterations) and Markov Chain Monte-Carlo iterations. The frequency of null alleles was estimated using the programme FreeNA (Chapuis \& Estoup, 2007). A summary of the microsatellite loci is presented in Table I. Expected heterozygosities varied considerably across loci (0.09-0.94); however, no evidence of departures from HWE and LE were found and the frequency of null alleles was negligible (e.g., <5.0\%). Cross-amplification success of these 11 loci was tested on eight istiophorid species. High levels of successful amplification were found across species (Table II).

The microsatellite loci described here will be useful for a variety of population structure and demographic history studies of the little understood T. georgii. They also show potential for use in similar studies of other istiophorid species, all of whom are exploited in multinational fisheries.

This project was supported by funding from the Guy Harvey Ocean Foundation and NOAA Fisheries (to M.S.S.), and a National Science and Engineering Council of Canada Graduate Fellowship (A.M.B.). We thank L. Beerkircher, J. Magnussen, D. Abercrombie, J. Graves and J. McDowell for samples used in this study. Microsatellite enrichment was carried out in the Pritzker Laboratory for Molecular Systematics and Evolution operated with support from the Pritzker Foundation.

\section{References}

Beerkircher, L., Arocha, F., Barse, A., Prince, E., Restrepo, V., Serafy, J. \& Shivji, M. (2009). Effects of species misidentification on population assessment of overfished white marlin Tetrapturus albidus and roundscale spearfish T. georgii. Endangered Species Research 9, 81-90.

Chapuis, M.-P. \& Estoup, A. (2007). Microsatellite null alleles and estimation of population differentiation. Molecular Biology and Evolution 24, 621-631.

Collette, B. B., Carpenter, K. E., Polidoro, B. A., Juan-Jordá, M. J., Boustany, A., Die, D. J., Elfes, C., Fox, W., Graves, J., Harrison, L. R., McManus, R., Minte-Vera, C. V., Nelson, R., Restrepo, V., Schratwieser, J., Sun, C.-L., Amorim, A., Brick Peres, M., 
Canales, C., Cardenas, G., Chang, S.-K., Chiang, W.-C., de Oliveira Leite, N. Jr, Harwell, H., Lessa, R., Fredou, F. L., Oxenford, H. A., Serra, R., Shao, K.-T., Sumaila, R., Wang, S.-P., Watson, R. \& Yáñez, E. (2011a). High value and long life - double jeopardy for tunas and billfishes. Science 333, 291-292.

Glenn, T. C. \& Schable, N. A. (2005). Isolating microsatellite DNA loci. Methods in Enzymology 395, 202-222.

Raymond, M. \& Rousset, F. (1995). GENEPOP (version 1.2): population genetics software for exact tests and ecumenicism. Journal of Heredity 86, 248-249.

Rousset, F. (2008). Genepop '007: a complete re-implementation of the GENEPOP software for Windows and Linux. Molecular Ecology Resources 8, 103-106.

Rozen, S. \& Skaletsky, H. J. (2000). Primer3 on the WWW for general users and for biologist programmers. In Bioinformatics Methods and Protocols: Methods in Molecular Biology (Krawetz, S. \& Misener, S., eds), pp. 365-386. Totowa, NJ: Humana Press.

Schuelke, M. (2000). An economic method for the fluorescent labeling of PCR fragments. Nature Biotechnology 18, 233-234.

Shivji, M. S., Magnussen, J. E., Beerkircher, L. R., Hinteregger, G., Lee, D. W., Serafy, J. E. \& Prince, E. D. (2006). Validity, identification, and distribution of the roundscale spearfish, Tetrapturus georgii, (Teleostei: Istiophoridae): morphological and molecular evidence. Bulletin of Marine Science 79, 483-491.

\section{Electronic References}

Arocha, F. \& Ortiz, M. (2006). Roundscale spearfish. ICCAT Field Manual. Chapter 2.1.8.4. Available at http://www.iccat.es/en/ICCATManual.asp (last accessed 18 August, 2012).

Collette, B., Amorim, A. F., Bizsel, K., Boustany, A., Carpenter, K. E., de Oliveira Leite, N. Jr, Die, D., Fox, W., Fredou, F. L., Graves, J., Viera Hazin, F. H., Hinton, M., Juan Jordá, M., Masuti, E., Minte Vera, C., Miyabe, N., Nelson, R., Oxenford, H., Restrepo, V., Schratwieser, J., Teixeira Lessa, R. P. \& Pires Ferreira Travassos, P. E. (2011b). Kajikia albida. IUCN Red List of Threatened Species. Version 2011.2. Available at www.iucnredlist.org (last accessed 26 January, 2012). 